DOI: 10.22591/magyurol.2018.1.maraza.2

\title{
Neoadjuváns- és adjuváns kemoterápia szerepe radikális cystectomiára alkalmas urotheliális tumoros betegeknél
}

\author{
Maráz Anikó dr., Varga Linda dr.
}

Szegedi Tudományegyetem, Onkoterápiás Klinika, Szeged (igazgató: Kahán Zsuzsanna dr.)

\author{
Levelezési cím: \\ Dr. Maráz Anikó \\ SzTE, Onkoterápiás Klinika \\ 6720 Szeged, Korányi fasor 12. \\ E-mail: \\ dr.aniko.maraz@gmail.com
}

\begin{abstract}
ÖSSZEFOGLALÁS
Bevezetés: Randomizált vizsgálatok és metaanalízisek alapján a lokálisan előrehaladott hólyagtumoros betegek túlélési adatai kedvezőbbek, ha a cystectomiát neoadjuvánsvagy adjuváns cisplatin bázisú kemoterápia egészíti ki. A neoadjuváns kezelés eredményei biztatóbbak a posztoperatívnál, mégis a hazai gyakorlatban csak az utóbbi években kezdődött meg alkalmazásának elterjedése. A nyugati országok betegpopulációjához képest előrehaladottabb stádiumban és több társbetegséggel rendelkező hazai betegek esetén már a hólyageltávolító műtét kivitelezése is igen nagy gyakorlatot és körültekintést igényel. Ezeknél a betegeknél a neoadjuváns kezelések akkor végezhetőek rutinszerüen, ha jól működő multidiszciplináris onkoteamek hoznak körültekintő döntést a cystectomia elvégzése előtt, valamint adekvátan definiált betegutak állnak rendelkezésre. A közlemény célja az izominvazív urotheliális daganatos betegeknél indikált radikális sebészi beavatkozáshoz kapcsolódó pre- és posztoperatív kemoterápia eredményeinek -, a vizsgálatok evidenciáinak -, valamint a nemzetközi ajánlásoknak az összefoglalása.
\end{abstract}

Beteganyag, módszer: Az ESMO és EAU guideline-ok alapján kiindulva ismertetésre kerülnek a neoadjuváns kemoterápiával kapcsolatos általános előnyök, mint a tumorszóródás korai csökkentése, a tumor down-staging lehetősége, az RO reszekciós arány javítása, a kemo-érzékenység megismerése, ahogyan az adjuváns kemoterápia mellett ismert benefit, mint a korrekt patológiai staging, valamint a definitív mütét koraibb időzítése. A neoadjuváns és adjuváns kemoterápia fontosabb 3. fázis vizsgálatait és metaanalízisek eredményeit értékeljük a kemoterápiás protokollok típusa -, a beválogatott betegek tumorstádiuma - és az eredményesség szempontjából. Eredmények: A neoadjuváns cisplatin bázisú kemoterápia hatására metaanalízisek alapján 5\%-os 5 éves túlélési benefit érhető el. Norvég 3. fázis vizsgálatban $8 \%$-0s, T3-as betegeknél 11\%-os benefit volt, amely a 8 éves követési ada-

\section{The role of neoadjuvant and adjuvant chemotherapy in urothelial cancer pati- ents suitable for cystectomy}

\section{SUMMARY}

Introduction: Based on randomized studies and meta-analyses, survival data of metastatic bladder cancer patients are more favorable if they receive neoadjuvant or adjuvant cisplatin-based chemotherapy before or after cystectomy. Data of neoadjuvant therapy are more favorable, although in Hungary, it has only been administered in the recent years. In comparison with the Western European countries, in Hungary, cystectomy requires significant experience and caution of the surgeon due to the advanced stages and the co-morbidities of the patients. In case of these patients, neoadjuvant therapies could only be performed if multidisciplinary tumor boards would make the decision before cystectomy, and if the procedures for the patients would be adequately defined. Our article summarizes the evidence of different studies, international guidelines, and the results of pre- and postoperative chemotherapy in case of muscle-invasive urothelial cancer patients who underwent radical cystectomy.

Patients, methods: Based on the ESMO and EAU guidelines, we interpret the different advantages of neoadjuvant chemotherapy, such as early decrease of tumor spreading, opportunity of tumor down-staging, improving the ratio of RO resection, knowledge of chemosensitivity, and the well-known benefits of the adjuvant chemotherapy, such as appropriate pathological staging and earlier definitive operation. We analyzed the result of the most important phase III studies and meta-analyses of neoadjuvant and adjuvant chemotherapy regarding the type of chemotherapy protocols, stage of the participants, and the effectivity. Results: Based on the meta-analyses, in case of neoadjuvant cisplatin-based chemotherapy, the 5 -year survival benefit is $5 \%$. In a Norwegian phase III study, the benefit was $8 \%$, in case of 
tok szerint $16 \%$. A neoadjuváns kemoterápiára jól reagáló betegeknél (pCR 12-50\% MVAC, 12-22\% GC protokoll esetén) még kedvezőbb a kimenetel. A cystectomia 3 hónapon túli késlekedésének nincs egyértelmüen szignifikáns kedvezőtlen hatása a túlélésre, ha a mütét előtt kemoterápia történik. Az adjuváns 3. fázis vizsgálatok, így a metaanalízisek eredményei is kevésbé egyértelműek, mint a neoadjuváns adatok, de öszszességükben kedvező trend észlelhető a kemoterápia hatására a túlélésben, különösen pT3/4 és/vagy N+ (valamint high grade vagy margin pozitív) esetekben. Az adjuvánsan indított kemoterápia utáni kimenetel kedvezőbb a késleltetett, progressziókor indított kemoterápia eredményeinél.

Következtetés: Az eddig ismert adatok alapján neoadjuváns cisplatin bázisú kemoterápia javasolt T2b-T4a tumorstátuszú betegeknek radikális cystectomia előtt. Cisplatinra alkalmatlan betegeknél neoadjuváns kezelés nem jár igazolt előnnyel. A T2aN0 stádiumú betegek kisebb tumortömege miatt kevesebb a mikrometasztázis potenciális jelenléte, emiatt a neoadjuváns kemoterápia ebben a stádiumban egyedileg mérlegelendő. Adjuváns kemoterápia javasolt minden pT3/4 és/vagy N+, vagy reszekciós szél pozitív betegnek, akinél neoadjuváns kemoterápia nem történt.

\section{KULCSSZAVAK}

UROTHELIÁLIS HÓLYAGDAGANAT, NEOADJUVÁNS KEMOTERÁPIA, ADJUVÁNS KEMOTERÁPIA, TÚLÉLÉS, CYSTECTOMIA

\section{Bevezetés}

Az urotheliális húgyhólyag-karcinóma a kilencedik leggyakoribb rosszindulatú daganat (1). Az esetek közel 70\%-ában 65 év feletti életkorban kerül diagnosztizálásra (2).

Felületes tumoroknak tekintjük a nem izominvazív daganatokat (non-muscle-invasive bladder cancer - NMIBC, Ta, Tis, T1), izominvazívnak (muscle-invasive bladder cancer - MIBC) azokat, amelyek a húgyhólyag falának izomrétegét beszűrik (T2), míg lokálisan elörehaladottnak a hólyagfalon túl a zsírszövetbe (T3), környező szervekre (T4) vagy a regionális nyirokcsomókba (szoliter-N1, többszörös medencei-N2, iliaca communis menti-N3) terjedő karcinómákat $(3,4)$. A diagnózis időpontjában a felületes, nem izominvazív hólyagtumorok előfordulási aránya 51-70\%, az izominvazív tumoroké 25-42\%, míg a primeren áttétes daganatoké 4-10\% a különböző közlemények alapján (5-9). A felületes daganatok kiújulási aránya magas, 30-50\% (5), de mortalitása alacsony, az összes eset kb. 50\%-a (1). A lokalizált, izominvazív daganatok csaknem 50\%-ban válnak áttétessé a betegség kórlefolyása során (5).
T3 patients, it was $11 \%$, and according to the 8 -year follow-up data, it was $16 \%$. The outcome is even more favorable in case of patients who respond well to neoadjuvant chemotherapy ( $p C R$ $12-50 \%$ MVAC, $12-22 \%$ in case of GC protocol). More than 3 months delay of cystectomy does not significantly reduce the survival if chemotherapy is performed before the operation. Results of adjuvant phase III studies and meta-analyses are not so unambiguous as neoadjuvant data, but chemotherapy seems to influence favorably the survival, especially in case of pT3/4 and/or N+ (and high grade or margin positivity) cases. The outcome of adjuvant chemotherapy is more favorable than in case of deferred chemotherapy started after progression.

Conclusions: Based on the current knowledge, neoadjuvant cisplatin-based chemotherapy is recommended for patients with T2b-T4a tumors before radical cystectomy. If the patients cannot receive cisplatin, neoadjuvant chemotherapy does not have any advantage. In case of T2aNO stage, the potential presence of micrometastases is lower due to the smaller tumor mass; thus, neoadjuvant chemotherapy can be administered individually in this stage. Adjuvant chemotherapy is recommended in case of all patients with pT3/4 and/or $\mathrm{N}+$ tumor or positive resection margin who did not receive neoadjuvant chemotherapy.

\section{KEYVORDS}

UROTHELIAL BLADDER CANCER, NEOADJUVANT CHEMOTHERAPY, ADJUVANT CHEMOTHERAPY, SURVIVAL, CYSTECTOMY

Az izominvazivitást mutató, lokalizált betegség standard kezelése a radikális cystectomia (RC) (5 éves teljes túlélés kb. 50\%), amelynek túlélési eredményei javíthatóak neoadjuváns (vagy adjuváns) kemoterápiával kiegészítve. A nyugati országok betegpopulációjához képest elörehaladottabb stádiumban és több társbetegséggel rendelkező hazai betegek esetén már a hólyageltávolító mútét kivitelezése is igen nagy gyakorlatot és körültekintést igényel. Ezeknél a betegeknél a neoadjuváns kezelések akkor végezhetőek rutinszerúen, ha jól múködő multidiszciplináris onkoteamek hoznak körültekintő döntést a cystectomia elvégzése előtt, valamint adekvátan definiált betegutak állnak rendelkezésre.

Kuratív terápiás lehetőség az ún. trimodális módszer (hólyagmegtartó mútét, sugárkezelés és kemoterápia [KT] kombinációja), amelynek hatására a radikális mútétet közelítő túlélési eredmények érhetőek el a hólyag megtartása mellett $(2,4)$. Szerény eredményességúnek volt mondható az áttétes betegek kezelése az elmúlt évekig, amíg csaknem önmagában a platinabázisú kombinált kemoterápiára kellett hagyatkozni. Hólyagtumorok kezelésében a molekulárisan célzott készítmények többsége a target receptorok meghatározása ellenére 
egyelőre nem hozott érdemi hasznot (10). Az immunellenőrzési pont blokkolása által az immunterápia új készítményei kedvező eredményeket mutatnak az áttétes vagy lokálisan előrehaladott urotheliális daganatok kezelésében, amely készítmények a jövőben áttörést hozhatnak a betegek túlélésének jelentős javításával.

\section{Kemoterápiás kombinációk - cisplatin vs. carboplatin}

Az urotheliális tumorok leggyakrabban alkalmazott szisztémás kezelési lehetősége a kemoterápia. A kemoterápiás kombinációk bázis készítményei a platinaszármazékok. Cisplatin tartalmú protokollok között alkalmazhatóak az MVAC (methothrexat/vinblastin/doxorubicin/cisplatin), CMV (cisplatin/methothrexat/vinblastin + leucovorin), GC (gemcitabin/ cisplatin) és PGC (paclitaxel/gemcitabin/cisplatin), míg carboplatint (CBP) tartalmazóak a G-CBP (gemcitabin/carboplatin), M-CAVI (methothrexat/carboplatin/vinblastin) sémák. Platinaszármazékot nem tartalmazó terápiás lehetőségek a vinflunin, a paclitaxel és a docetaxel, amelyek leginkább másodvonalban indikáltak $(2,5)$.

A cisplatinbázisú kombinációkkal kedvezőbb terápiás eredmény érhető el, mint CBP-vel. A teljes tumorválasz (overall remission rate - ORR) aránya 50-60\%, az 1. vonalban elérhetó medián teljes túlélés (overall survival - OS) 15 hónap, az 1 éves OS 60\%, míg CBP-bázisú kombinációk esetén 36\% ORR, medián OS 9 hónap, 1 éves OS 37\% érhető el $(2,5)$, így lehetőség szerint a cisplatin bázisú kombinációk alkalmazása javasolt. Cisplatin bázisú kemoterápiára azonban a betegek kb. fele nem alkalmas a gyenge általános állapot, csökkent vesefunkciós érték, halláscsökkenés, perifériás neuropátia vagy kardiális okok miatt $(5,11)$ (1. táblázat).
1. tÁBlÁZAT: Cisplatin KezelÉSRE ALKalmatLANSÁG KRITÉRIUMAI (11)

\section{CISPLATIN KEZELÉSRE ALKALMATLANSÁG} (LEGALÁBB 1 FAKTOR JELENLÉTE)

Vesefunkció - kreatinin clearance $<60 \mathrm{ml} / \mathrm{min}$

CTCAE v. 4. grade $\geq 2$ halláscsökkenés

CTCAE v. 4. grade $\geq 2$ perifériás neuropátia

WHO vagy ECOG PS $\geq 2$ vagy Karnofsky PS 60-70\%

NYHA III. szívelégtelenség

Rövidítések: CTCAE - Common Terminology Criteria Adverse Events version 4.0, ECOG - Eastern Cooperative Oncology Group, NYHA - New York Heart Association, PS - Performance Status, WHO-World Health Organisation

\section{Kemoterápia időzítése - neoadjuváns (NA)/adjuváns/késleltetett}

\section{Neoadjuváns alkalmazás}

A definitív mútétre dedikált betegek sebészi beavatkozást megelőző, azaz preoperatív kezelését nevezzük neoadjuváns terápiának, amennyiben a folyamat potenciálisan reszekábilisnek tekinthető. A lokálisan előrehaladott, technikailag irreszekábilis betegek esetleges mútét előtti kemoterápiás kezelését konverziós kemoterápiának nevezzük (12).

Elónyei a tumorszóródás és a mikrometasztázisok korai csökkentése, a tumor down-staging lehetősége, a TO, NO, RO reszekciós arány javítása, a kemo-érzékenység in-vivo megismerése, a kemoterápiára alkalmas betegek nagyobb aránya a radikális cystectomia előtt, valamint hogy randomizált vizsgálatban nem

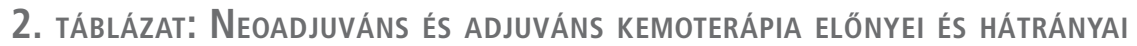

\begin{tabular}{|c|c|c|}
\hline & Neoadjuváns KT & Adjuváns KT \\
\hline \multirow[t]{6}{*}{ Elöny } & $\begin{array}{l}\text { a tumorszóródás és a mikrometasztázisok korai } \\
\text { csökkentése }\end{array}$ & korrekt patológiai staging áll rendelkezésre \\
\hline & tumor down-staging lehetősége & a definitív mútét elvégzése nem késlekedik \\
\hline & TO, NO, RO reszekciós arány javítása & \\
\hline & kemo-érzékenység in-vivo megismerése & \\
\hline & kemoterápiára alkalmas betegek nagyobb aránya & \\
\hline & $\begin{array}{l}\text { randomizált vizsgálatban nem volt a grade 3-4. } \\
\text { posztoperatív komplikációkban különbség }\end{array}$ & \\
\hline \multirow[t]{3}{*}{ Hátrány } & nincs korrekt patológiai staging & in vivo kemoszenzitivitás nem ismert \\
\hline & túlkezelés potenciális esélye & $\begin{array}{l}\text { gyengébb a betegek általános állapota radikális } \\
\text { cystectomia után }\end{array}$ \\
\hline & $\begin{array}{l}\text { a definitív mútét késlekedése a kemo-rezisztens } \\
\text { betegeknél }\end{array}$ & $\begin{array}{l}\text { mútéti felgyógyulás miatt a betegek harmada nem } \\
\text { alkalmas onkológiai kezelésre }\end{array}$ \\
\hline
\end{tabular}


volt a grade 3-4 posztoperatív komplikációkban különbség (skandináv vizsgálatban 71\%-ban 3 ciklus KT történt) (4, 13). Hátrányai, hogy nincs korrekt patológiai staging (képalkotó staging 70\%-ban korrekt), a túlkezelés potenciális esélye, továbbá a definitív mútét késlekedése a kemo-rezisztens betegeknél (bár nincs adat az RC késlekedésének negatív hatásáról, csak a kemo-naív betegeknél) (4) (2. táblázat).

\section{Neoadjuváns KT eredményessége}

A NA-kemoterápia valós hasznával kapcsolatosan éveken keresztül bizonytalan álláspontok láttak napvilágot annak ellenére, hogy az 1980-as évektől kezdődően több klinikai vizsgálatban bizonyították a cystectomiára alkalmas T2-T3 tumorstádiumú betegek NA-kezelést követő cystectomia utáni 26-33\%-os halálozási rizikó csökkenését a csak cystectomiához képest (13-16). A NA cisplatinbázisú, 2-3 ciklus KT hatására a legújabb metaanalízisek alapján is (11 trial 3005 beteg) 5\% 5 éves OS benefit, míg 9\% 5 éves betegségmentes túlélési (disease free survival - DFS) elöny detektálható (4, $15,17)$.

Egy skandináv 3. fázis vizsgálatban 8\%, a T3-as betegeknél $11 \%$ benefit volt elérhető a NA KT hatására a csak cystectomiához képest, amely 8 éves követés után 16\%-ra emelkedett (18). Az elemzések alapján csak a cisplatinbázisú kombináció okoz előnyt, emiatt az NA-kezelés a cisplatin KT-ra fit betegeknek javasolt. A KT hatására kialakult patológiai komplett remisszió esetén (azaz pTO NO betegeknél) még jelentősebb OS javulás volt detektálható $(4,17)$.

\section{Neoadjuváns KT kombinációi - GC vagy MVAC?}

A két leggyakrabban használt kemoterápiás kombináció esetén felmerül a kérdés, hogy neoadjuváns kezelések során melyik séma az előnyösebb. Bár csak lokálisan előrehaladott vagy áttétes betegek elsővonalbeli terápiájával vannak direkt összehasonlító vizsgálatok a protokollokkal, az elemzések a két kombináció esetén azonos OS, 5 éves OS és progressziómentes túlélést (PFS) eredményeztek, a GC kombináció lényegesen kedvezőbb toxicitási arányával $(19,20)$. Indirekt összehasonlítások alapján neoadjuváns kezelés során a pT0/pT1 arány azonos volt az MVAC és GC sémákkal. Az NA KT-ra jól reagáló betegeknél (pCR 12-50\% MVAC, 12-22\% GC) mindkét protokoll mellett még kedvezőbb volt a kimenetel. 8 éves követés után 16\%-os halálozási rizikójavulást és a 10 éves OS 30-ról 36\%-ra emelkedését eredményezték. A távoli áttétek aránya is javult, a lokoregionális kontroll változatlan maradt (4, 17, 21).

\section{Neoadjuváns KT kinél előnyös?}

Jól ismert tény, hogy az izominvazív tumor diagnózisától a cystectomiáig eltelt idő 3 hónapon túli késlekedése rontja a túlélést $(22,23)$. Neoadjuváns kemoterápia esetén azonban a cystectomia késlekedésének nincs egyértelmúen szignifikáns kedvezőtlen hatása a betegek túlélésére (4). A NA kemoterápia egyik célja a mikrometasztázisok arányának korai, gyors csökkentése. Mivel a kis kiterjedésú T2 (új klasszifikáció szerint T2a - izomréteg belső fele érintett) tumorok esetén ennek aránya alacsonyabb az elörehaladott tumorokéhoz képest, emiatt a NA KT alkalmazása a T2b-T3b (korábbi klasszifikáció szerint T3) tumorok esetén a túlélés javítása és a potenciális down-staging miatt kiemelten javasolt. További kérdést vet fel a T2 tumorok klinikai stádiumának pontossága, mivel a mútéti preparátumokban 43-73\%-ban magasabb patológiai tumorstádiumot találtak, ami ugyancsak a NA KT javallatát erősíti $(4,24)$. A T4-es tumorok esetén a mútéti preparátumokban a makroszkópos nyirokcsomó-áttétek aránya magas, ebben a stádiumban a konverziós KT célja a reszekabilitás javítása és a downstaging $(4,18)$.

\section{Neoadjuváns kemoterápia összefoglalva}

Az eddig ismert eredmények alapján neoadjuváns cisplatinbázisú KT javasolt T2b-T4a NO MO, esetleg N+ tumorstátuszú betegeknek radikális cystectomia előtt.

Cisplatinra alkalmatlan betegeknél neoadjuváns kezelés nem jár igazolt előnnyel.

A T2aNO stádiumú betegek kisebb tumortömege miatt kevesebb a mikrometasztázis potenciális jelenléte, emiatt a neoadjuváns KT egyedileg mérlegelendő (4).

\section{Adjuváns alkalmazás}

Adjuváns kemoterápiának nevezzük a definitív mútétet követő posztoperatív kezelést (12).

Előnye, hogy korrekt patológiai staging áll rendelkezésre, valamint, a definitív mútét elvégzése nem késlekedik (4).

Hátrányai, hogy az in vivo kemoszenzitivitás nem ismert, gyengébb a betegek általános állapota radikális mútétet követően, az esetlegesen elhúzódó mútéti felgyógyulás miatt a betegek harmada nem lesz alkalmas onkológiai kezelésre, emiatt kisebb arányú a kemoterápiára alkalmas betegcsoport (4) (2. táblázat).

\section{Adjuváns KT eredményessége}

Az adjuváns KT valós evidenciája pT3/4 és/vagy N+ M0 betegeknél kérdéses. A korábbi randomizált vizsgálatok adatai alapján nem volt egyértelmú adat arra vonatkozóan, hogy az adjuváns kemoterápia hatására túlélés-javulás jön létre. Az említett 6 vizsgálat (491 eset) felében az alacsony elemszám, a korai vizsgálatzárás, valamint az irreleváns végpontok miatt nem volt detektálható előny az adjuváns KT hatására. Ezekben a vizsgálatokban 4 ciklus CMV, CISCA, MVAC, MVEC, CM, C-monoterápia alkalmazása történt (25-27). Az újabb adjuváns 3. fázis vizsgálatokkal (9 trial, 945 beteg), amelyekből 3 vizsgálatban modern KT-s kombinációkat (GC, PGC) alkalmaztak (27-29), az OS javulásában 23\%-OS, a DFS-ben 34\%, míg az N+ betegek DFS-ében $36 \%$ rizikócsökkenés volt detektálható (27). Összességében kedvező trend észlelhető az adjuváns KT hatására a túlélésben, különösen pT3-4 és/vagy N+ stádiumban, de az alacsony esetszámok miatt az alkalmazás evidenciája alacsony. Adjuváns KT-ból leginkább profitálhatnak a high risk betegek (pT3-4 és/vagy N+, pozitív sebészi szél, high grade tumor), ha neoadjuváns KT nem történt, amelynek lehetőségéről a betegeket informálni kell $(4,27)$. 


\section{Adjuváns vs. késleltetett KT}

Az EORTC 30994-es fázis III-as trial-ében pT3/T4 és/vagy N+ betegek radikális cystectomia utáni azonnali 4 ciklus adjuváns kemoterápiás kezelésének az összehasonlítását végezték a relapszuskor alkalmazott 6 ciklus kemoterápia eredményével (GC, MVAC vagy high-dose MVAC-protokoll formájában). Az előzetesen tervezett betegszámot ebben a vizsgálatban sem tudták beválogatni az elemzésbe. A progressziómentes túlélésben a közvetlen mútét után alkalmazott KT hatására domináns elóny mutatkozott a rizikó 48\%-os csökkenésével, míg a teljes túlélésben szignifikáns előny nem volt detektálható, bár a halálozás rizikója 22\%-kal csökkent (30).

\section{Adjuváns KT összefoglalva}

Az adjuváns 3. fázis vizsgálatok (9 trial) eredményei kevésbé erőteljesek (OS és DFS benefit), mint a neoadjuváns adatok. Összességében kedvező trend észlelhető az adjuváns KT hatására a túlélésben, különösen pT3-4 és/vagy N+ (és reszekciós szél pozitív vagy high grade) stádiumban, ha neoadjuváns KT nem történt. Az adjuváns $K T$ utáni PFS és OS eredmények kedvezőbbek, mint a késleltetett, azaz progressziókor alkalmazott KT kimenetele.

\section{A jövő lehetőségei}

Jelenleg nem ismertek magas evidenciájú adatok a NA kemoterápia optimális betegszelekciójáról. A KT alkalmazása a kezelésre nem reagáló betegek esetén jelenthet hátrányt az eredménytelen terápia miatt késlekedő radikális cystectomia kedvezőtlenebb kimenetele miatt. A NA kezelések hatékonysága potenciálisan több módon javítható. Az egyik lehetőség az urotheliális daganatok genetikai profiljának megismerése, amely alapján lehetővé válhat a személyre szabott terápia és a potenciális non-responderek kiválasztása. Egyes közlemények alapján körvonalazódik a bazális, luminális és p53-like altípusok szerinti felosztás, amelyek között az utóbbi altípus kemo-rezisztensnek tünik (31).

Egy másik lehetséges út az urotheliális daganatok kezelésében áttörést jelentő PD-1/ PD-L1 gátló immunellenőrzési pont gátlók neoadjuváns és adjuváns indikációkban történő alkalmazása, amellyel kapcsolatosan számos klinikai vizsgálat van folyamatban mind az öt, FDA által urotheliális daganat kezelésére befogadott készítménnyel (pembrolizumab, atezolizumab, nivolumab, durvalumab, and avelumab) (32).

\section{Következtetések}

- Az eddig ismert eredmények (11 trial, 5\% 5éOS és 9\% DFS előny vs. cystectomia) alapján neoadjuváns cisplatinbázisú KT javasolt T2b-T4a N0, esetleg N+ tumorstátuszú betegeknek radikális cystectomia előtt.

- Cisplatinra alkalmatlan betegeknél neoadjuváns kezelés nem jár igazolt előnnyel.

- A TZaNO stádiumú betegek kisebb tumortömege miatt kevesebb a mikrometasztázis potenciális jelenléte, emiatt a neoadjuváns KT ebben a stádiumban egyedileg mérlegelendó.

- Az adjuváns 3. fázis vizsgálatok (9 trial) eredményei kevésbé erőteljesek (OS és DFB benefit), mint a neoadjuváns metaanalízis adatok.

- Összességében kedvező eredmény észlelhető az adjuváns KT hatására a túlélésben, különösen pT3-4 és/vagy N+ stádiumban (high grade vagy rezekciós szél pozitív esetekben is), ha neoadjuváns KT nem történt.

- Az adjuváns kemoterápia adása kedvezőbb eredményességú, mint a késleltetett, progressziókor alkalmazott kezelés.

- Neoadjuváns KT > Adjuváns KT > Késleltetett KT.

\section{Irodalom}

1. Ratta $R$, Zappasodi R, Raggi $D$, et al. Immunotherapy advances in uro-genital malignancies. Critical Reviews in Oncology/Hematology 2016; 105: 52-64. https://doi.org/10.1016/j.critrevonc.2016.06.012

2. Bellmunt J, Orsola A, Leow JJ, et al. Bladder cancer: ESMO Practice Guidelines for diagnosis, treatment and follow-up. Ann Oncol 2014; 25: iii40-8. https://doi.org/10.1093/annond/mdu223

3. Babjuk M, Böhle A, Burger M, et al. EAU Guidelines on Non-Muscle-invasive Urothelial Carcinoma of the Bladder: Update Eur Urol 2017; 71(3): 447-461. https://doi.org/10.1016/j.eururo.2016.05.041

4. Witjes JA, Lebret T, Compérat EM, et al. Updated 2016 EAU Guidelines on Muscle-invasive and Metastatic Bladder Cancer. Eur Urol 2017; 71: 462-475. 2017.

5. NCCN Guidelines Version 2 2016. /www.ncen.org/professionals/physician_gls/pdf/bladder.pdf

6. Howlader N, Noone AM, Krapcho M, et al. (eds). SEER Cancer Statistics Review, 1975-2011, National Cancer Institute. Bethesda, MD, http://seer. cancer.gov/csr/1975_2011/, based on November 2013 SEER data submis- sion, posted to the SEER web site, April 2014.

7. Sharma $S$, Ksheersagar $P$ and Sharma P. Diagnosis and treatment of bladder cancer. Am Fam Physician 2009; 80: 717-23.

8. Kaufman DS, Shipley WU and Feldman AS. Bladder cancer. Lancet 2009; 374: 234-49. https://doi.org/10.1016/S0140-6736(09)60491-8

9. American Cancer Society 2014: Bladder Cancer (http://www.cancer.org/ acs/groups/cid/documents/webcontent/003085-pdf.pdf); last accessed June 2015

10. Kessel KE, Zuiverloon TC, Alberts AR, et al. Targeted therapies in bladder cancer: an overview of in vivo research. Nat Rev Urol 2015; 12: 681-94. https://doi.org/10.1038/nrurol.2015.231

11. Galsky MD, Hahn NM, Rosenberg JE, et al. Defining „cisplatin ineligible” patients with metastatic bladder cancer. J Clin Oncol 2011; 29: 7; abstr 238.

12. NCI Dictionary of Cancer Terms https:/wwww.cancer.gov/publications/ dictionaries/cancer-terms?cdrid $=45587$

13. Grossman HB1, Natale RB, Tangen CM, et al. Neoadjuvant chemother- 
apy plus cystectomy compared with cystectomy alone for locally advanced bladder cancer. N Engl J Med 2003; 28; 349(9): 859-66.

14. David KA, et al. Low incidence of perioperative chemotherapy for stage III bladder cancer 1998 to 2003: a report from the National Cancer Data Base. J Urol 2007; 178: 451. https://doi.org/10.1016/j. juro.2007.03.101

15. Advanced Bladder Cancer (ABC) Meta-analysis Collaboration. Neoadjuvant chemotherapy in invasive bladder cancer: update of a systematic review and meta-analysis of individual patient data advanced bladder cancer (ABC) meta-analysis collaboration. Eur Urol 2005; 48(2): 202-5. https://doi.org/10.1016/j.eururo.2005.04.006

16. International Collaboration of Trialists, on behalf of the Medical Research Council Advanced Bladder Cancer Working Party the European Organisation for Research and Treatment of Cancer Genito-Urinary Tract Cancer Group, the Australian Bladder Cancer Study Group, the National Cancer Institute of Canada Clinical Trials Group, et al. International Phase III Trial Assessing Neoadjuvant Cisplatin, Methotrexate, and Vinblastine Chemotherapy for Muscle-Invasive Bladder Cancer: Long-Term Results of the BA06 30894 Trial. J Clin Oncol 2011 Jun 1; 29(16): 2171-2177. https://doi.org/10.1200/JCO.2010.32.3139

17. Yin M, Joshi M, Meijer RP, et al. Neoadjuvant Chemotherapy for Muscle-Invasive Bladder Cancer: A Systematic Review and Two-Step Meta-Analysis Oncologist 2016; 21(6): 708-715.

18. Sherif $A$, et al. Neoadjuvant cisplatinum based combination chemotherapy in patients with invasive bladder cancer: a combined analysis of two Nordic studies. Eur Urol 2004; 45: 297. https://doi.org/10.1016/j. eururo.2003.09.019

19. De Santis M, Bellmunt J, Mead G, et al. Randomized phase I/III trial assessing gemcitabine/carboplatin and methotrexate/carboplatin/vinblastine in patients with advanced urothelial cancer "unfit" for cisplatin-based chemotherapy: phase II--results of EORTC study 30986. J Clin Oncol 2009; 27(33): 5634-9. https://doi.org/10.1200/JCO.2008.21.4924

20. Von der Maase H, Sengelov L, Roberts JT, et al. Long-term survival results of a randomized trial comparing gemcitabine plus cisplatin, with methotrexate, vinblastine, doxorubicin, plus cisplatin in patients with bladder cancer. J Clin Oncol 2005; 23: 4602-4608. https://doi. org/10.1200/JCO.2005.07.757

21. Griffiths $\mathrm{G}$, et al. International phase III trial assessing neoadjuvant cisplatin, methotrexate, and vinblastine chemotherapy for muscle-invasive bladder cancer: long-term results of the BA06 30894 trial. J Clin Oncol 2011; 29: 2171. https://doi.org/10.1200/JCO.2010.32.3139

22. Lee $C$, Madii $R$, Daignault $S$, et al. Cystectomy delay more than 3 months from initial bladder cancer diagnosis results in decreased disease specific and overall survival. J Urol 2006; 175(4): 1262-1267. https:/ doi.org/10.1016/S0022-5347(05)00644-0

23. Sanchez-Ortiz RF, et al. An interval longer than 12 weeks between the diagnosis of muscle invasion and cystectomy is associated with worse outcome in bladder carcinoma. J Urol 2003; 169: 110. https://doi.org/10.1097/00005392200301000-00027 https://doi.org/10.1016/50022-5347(05)64047-5

24. Rosenblatt $R$, et al. Pathologic downstaging is a surrogate marker for efficacy and increased survival following neoadjuvant chemotherapy and radical cystectomy for muscle-invasive urothelial bladder cancer. Eur Urol 2012; 61: 1229. https://doi.org/10.1016/j.eururo.2011.12.010

25. Sylvester $R$, et al. The role of adjuvant combination chemotherapy after cystectomy in locally advanced bladder cancer: what we do not know and why. Ann Oncol 2000; 11: 851. https:/doi. org/10.1023/A:1008399130226

26. ABC Meta-analysis Coll. Adjuvant chemotherapy in invasive bladder cancer: a systematic review and meta-analysis of individual patient data Advanced Bladder Cancer (ABC) Meta-analysis Collaboration. Eur Urol 2005; 48: 189. https://doi.org/10.1016/j.eururo.2005.04.005

27. Leow JJ, et al. Adjuvant chemotherapy for invasive bladder cancer: a 2013 updated systematic review and meta-analysis of randomized trials. Eur Urol 2014; 66: 42. https://doi.org/10.1016/j.eururo.2013.08.033

28. Cognetti F, et al. Adjuvant chemotherapy with cisplatin and gemcitabine versus chemotherapy at relapse in patients with muscle-invasive bladder cancer submitted to radical cystectomy: an Italian, multicenter, randomized phase III trial. Ann Oncol 2012; 23: 695. https:/doi. org/10.1093/annond/mdr354

29. Paz-Ares, L.G., et al. Randomized phase III trial comparing adjuvant paclitaxel/gemcitabine/cisplatin (PGC) to observation in patients with resected invasive bladder cancer: Results of the Spanish Oncology Genitourinary Group (SOGUG) 99/01 study. J Clin Oncol 2010; 28(18 Suppl). https://doi.org/10.1200/jco.2010.28.18_suppl.l.ba4518

30. Sternberg $\mathrm{CN}$, et al. Immediate versus deferred chemotherapy after radical cystectomy in patients with pT3-pT4 or $\mathrm{N}+\mathrm{M} 0$ urothelial carcinoma of the bladder (EORTC 30994): an intergroup, open-label, randomised phase 3 trial. Lancet Oncol 2015; 16: 76. https:/doi.org/10.1016/ S1470-2045(14)71160-X

31. Choi W, Czerniak B, Ochoa A, et al. Intrinsic basal and luminal subtypes of muscle-invasive bladder cancer. Nat Rev Urol 2014; 11(7): 400-10. https://doi.org/10.1038/nrurol.2014.129

32. Maráz A, Géczi L. Immunterápia szerepe az urotheliális daganatok modern kezelésében. Magyar Onkológia 2017; 61: 139-146. 